\title{
Haemato-biochemical and ionic regulatory responses of the hybrid catfish, Heteroclarias, to sublethal concentrations of palm oil mill effluents
}

\author{
Olufemi D. Owolabi ${ }^{*}$, Saratu I. Abdulkareem ${ }^{1}$ and Adefemi O. Ajibare ${ }^{2}$
}

\begin{abstract}
Background: Pollution arising from the noxiousness of palm oil mill effluent (POME) has become a serious threat to aquatic biotas. However, a paucity of information exists on fish response to POME-mediated oxidative stress, lipid peroxidation, haemato-biochemical, enzymatic and ionic changes. This study, therefore, evaluates the effects of 28-day exposure of Heteroclarias, a hybrid catfish, to POME. Juvenile Heteroclarias ( $n=350$, average weight: $11.90 \pm 0.70 \mathrm{~g}$ and average length: $9.04 \pm 0.71 \mathrm{~cm}$ ) were exposed to sublethal concentrations (0-control, 4.00, 8.00 and $12.00 \mathrm{mg} / \mathrm{l})$ of POME to determine its effects on red blood cells (RBC), haemoglobin (HB), packed cell volume (PCV), white blood cells (WBC), mean cell haemoglobin (MCH), mean cell haemoglobin concentration (MCHC) and mean cell volume (MCV). The activities of alanine aminotransaminase (ALT), aspartate aminotransaminase (AST), lactate dehydrogenase $(\mathrm{LDH})$, catalase (CAT), superoxide dismutase (SOD), glutathione peroxidase (GPX) and the levels of malondialdehyde $(\mathrm{MDA})$, calcium $\left(\mathrm{Ca}^{+}\right)$, potassium $\left(\mathrm{K}^{+}\right)$, magnesium $\left(\mathrm{Mg}^{2+}\right)$ and sodium $\left(\mathrm{Na}^{+}\right)$ions were also assayed in the gill and liver.

Results: Exposure to POME caused significant $(p<0.05)$ concentration-dependent decrease in RBC, HB, PCV, MCV, $\mathrm{MCH}$ and $\mathrm{MCHC}$ values, whereas a significant $(p<0.05)$ concentration-dependent increase in WBC was observed in POME-exposed fish compared to the control. ALT, AST, LDH, GPX, SOD and CAT activities in the gill and liver significantly $(p<0.05)$ increased in a concentration-dependent manner. MDA level significantly $(p<0.05)$ increased in the gill relative to control, while in the liver it was insignificantly different. Both tissues exhibited an increase in $\mathrm{Ca}^{+}, \mathrm{K}^{+}, \mathrm{Mg}^{2+}$ and $\mathrm{Na}^{+}$levels at the highest toxicant concentration with a rise of 77.93, 38.46, 109.54 and $41.99 \%$ recorded for the electrolytes in the gill and 79.17, 26.92, 55.48 and $38.78 \%$ in the liver above the control value, respectively. The levels of all the electrolytes except $\mathrm{K}^{+}$were higher in the gill than the liver and were in the order: $\mathrm{Na}^{+}>\mathrm{K}^{+}>\mathrm{Mg}^{+}>\mathrm{Ca}^{2+}$ in both tissues.
\end{abstract}

Conclusions: These results may be used as a suitable tool for pollution assessment and policy formulation to mitigate the discharge of untreated POME into aquatic ecosystems and their impacts on resident organisms.

Keywords: Chronic toxicity, Haematology, Enzymatic changes, Malondialdehyde, lonic changes, Untreated palm oil mill effluent

\footnotetext{
*Correspondence: olulabi47@yahoo.com; olulabi@unilorin.edu.ng

${ }^{1}$ Fisheries and Hydrobiology Laboratory, Department of Zoology,

University of Ilorin, P.M.B. 1515, Ilorin 240003, Nigeria
}

Full list of author information is available at the end of the article

\section{Background}

Elaeis guineensis, the oil palm, is an important oil crop of commercial value in Nigeria. The production of palm oil has become a major vocation in many communities 
where oil palm is grown. It provides income for farmers and their dependants and has contributed to the Nigerian gross domestic product (GDP). Besides, palm oil is used in Nigerian traditional medicine as an antidote for cough, food poisoning, allergies and other ailments. Nigeria, according to United States Department of Agriculture, is presently the fifth leading producer of palm oil in the world, with $1.5 \%$ or 1.03 million metric tonnes (MT) of global total output (World Bank 2018). Nigeria has been reported to be the largest consumer of palm oil in Africa (World Bank 2018). It has also been estimated that about 3 million MT of fats and oil was consumed in 2018 , with palm oil contributing $44.7 \%$ or 1.34 MT (World Bank 2018). Presently, Nigeria is experiencing a shortfall of about $0.32 \mathrm{MT}$ below its production capacity. Nigeria's quest to maintain its market dominance in the palm oil industry would, therefore, means more cultivation and processing of palm oil and generation of more wastes that could be discharged into water bodies. Thus, while palm oil production could be of benefit to man, on the one hand, the environmental impacts of the wastes generated on aquatic biota, on the other, should not be overlooked. The processing of palm oil involves a large volume of water used for oil extraction; hence, large- or medium-scale palm oil industries are sited close to water bodies. Studies have shown that during oil extraction, 5-7.5 tonnes of water could end up as effluent for every one tonne of palm oil extracted (Okwute and Isu 2007; Wu et al. 2009). Most of these palm oil mill effluents (POME), particularly those produced from the small-scale industries, are channelled from the production units, directly without prior treatment, into the aquatic ecosystems. The POME, due to its high concentration of organic matter, heavy metals, fatty acids, protein and carbohydrates (Chan and Chooi 1984), could alter the quality of the recipient water (Okwute and Isu 2007). POME, when discharged into water bodies, may cause fouling, smelling, sliming and hypoxic condition (Vithana et al. 2019), resulting into fish kills and may also hinder the accessibility of the riparian communities to safe and clean water for domestic (Ezemonye et al. 2007), fishing, livestock and irrigation purposes. In Nigeria, there is presently lack of information on specific management guidelines for POME, and hence, the safety concerns of the effluents in aquatic systems are not properly understood. Considering the likely impacts POME may have on fish species, livestock and humans upon being discharged into water bodies, in which hitherto there are no toxicological guidelines concerning its exposure; the need to document vital information that may be useful in mitigating environmental challenges arising from POME is pertinent.
Heteroclarias, an inter-generic hybrid of ${ }^{\star}$ Clarias angullaris $\times$ ? Heterobranchus bidorsalis, is a hardy food fish that is very popular in Nigeria. The pure lines, Clarias angullaris and Heterobranchus bidorsalis, are two most popular African Clariid catfishes commercially grown in freshwater ponds, lakes and rivers in Nigeria. They are highly relished as they serve as delicacies among many tribes. In practical aquaculture, hybrid production is undertaken against the backdrop of enhancing faster growth, survival and genetic traits improvement. Studies have shown that Heteroclarias is very hardy as much as its pure lines (Diyaware et al. 2013). It is, therefore, a good piscine model for ecotoxicological assessment because of its resilience and adaptation to laboratory condition, thus informing its selection for this study. Fish health is a function of water quality; hence, the study of the effects of POME on some aspects of the catfish physiology is pertinent to the understanding of its requirement for survival and sustainable management. Literature is inundated with the reports of several authors describing the impacts of palm oil mill effluents (POME) on aquatic ecosystem and its resident biota, particularly fish. Okwute and Isu (2007) reported that POME can deleteriously alter the physicochemical properties of water, which could lead to habitat loss and thus affect other biological components therein. Exposure to POME resulted in the disruption of phytoplankton diversity (Muliari and Zulfahmi 2016), hepatic alterations causing dysfunction (Zulfahmi et al. 2017), a decline in the reproductive index (GSI) and shrinkage of oocyte diameter (Zulfahmi et al. 2018). Furthermore, exposure to POME has been reported to cause a reduction in the concentration of reproductive hormones (Muliari et al. 2019), thus compromising the functionality of the fish reproductive system with a far-reaching implication on conservation, sustainable exploitation and management of fisheries resources. Muliari et al. (2020) also revealed that increased malformations, decreased hatching, and survival rate of fish larvae occurred following POME exposure. Despite the various impacts of POME reported by these authors, a paucity of information still exists on how the underlying physiological and biochemical factors responsible for the different toxicity endpoints earlier reported by these authors are mediated. Specifically, the use of haematological and biochemical parameters as biomarkers in the assessment of POME toxicity in fish is yet to be explored. Haematological and biochemical parameters have been useful in biomonitoring as possible biomarkers of physiological and pathological changes in animals subjected to environmental perturbations. The induction or inhibition of these parameters in fish is a rapid approach to evaluating the potentially debilitating effects of xenobiotics on aquatic biota as warning signs 
of impending health risks. Since biochemical responses directly related to the processes of gas exchange, biotransformation or detoxification and osmoregulation typically occur in fish gill and liver, and these organs are the target sites for optimal radical generation and numerous oxidative reactions (Alimba et al. 2013), the gill and liver were chosen for this study. This study is, therefore, aimed at providing more information relevant to fish response during POME-mediated oxidative stress, lipid peroxidation, haemato-biochemical, enzymatic and electrolytic changes. In general, this would serve as a valuable supplement to the earlier records of a fish general response to POME intoxication for management and planning purposes.

\section{Methods}

\section{Effluent collection and physicochemical parameters characterisation}

Samples of raw effluent emanating directly from palm oil mill were collected at a point of discharge into Okeawon River situated in Okeawon village (N $7^{\circ} 54^{\prime} 0^{\prime \prime}$, E $\left.4^{\circ} 25^{\prime} 0^{\prime \prime}\right)$ in Surulere Local Government Area of Oyo State nearby Ogbomoso (N $8^{\circ} 7^{\prime} 59.9988^{\prime \prime}$, E $4^{\circ} 15^{\prime} 0^{\prime \prime}$ ), South west, Nigeria. Collection of the raw effluent sample was done in a stoppered-20-L container which had earlier been sterilised prior use. In the laboratory, the metal content and physicochemical parameters of POME were determined before the experiment commenced. Physical parameters (total dissolved solids (TDS), $\mathrm{pH}$, and conductivity) were estimated using the multi-meter probe (HQ40, Hach Lange GmbH, Germany), while chemical parameters (biological oxygen demand (BOD), chemical oxygen demand (COD), nitrate $\left(\mathrm{NO}_{3}{ }^{-}\right)$and sulphates $\left(\mathrm{SO}_{4}{ }^{2-}\right)$ of effluent samples were characterised in line with the local (National Environmental Standard Regulation Enforcement Agency [NESREA]) and international (the United States Environmental protection Agency [USEPA]) regulatory stipulations using the American Public Health Association (APHA) (2005) procedure. These regulatory bodies (NESREA and USEPA) set the maximum thresholds for contaminants levels in wastewater and other xenobiotics. The acidification of the effluent was done using $5 \mathrm{HNO}_{3}$, after which it was stored at $4{ }^{\circ} \mathrm{C}$ prior analysis (Tsarpali and Dailianis 2012). The concentration of heavy metals (copper $(\mathrm{Cu})$, cadmium $(\mathrm{Cd})$, iron $(\mathrm{Fe})$, lead $(\mathrm{Pb})$, and zinc $(\mathrm{Zn}))$ were evaluated using the PerkinElmer Analyst atomic absorption spectrometer (AAS). A known concentration of each of the metal investigated was used to authenticate the analysis of metals.

Fish collection, maintenance and experimental procedure Juvenile Heteroclarias specimens $(n=350$, average weight: $11.90 \pm 0.70 \mathrm{~g}$ and average length $9.04 \pm 0.71 \mathrm{~cm}$ ) from the same pure lines were procured from a commercial fish hatchery in Ilorin $\left(10^{\circ} 53^{\prime} 0^{\prime \prime} \mathrm{N}, 4^{\circ} 1^{\prime} 0^{\prime \prime} \mathrm{E}\right)$, Kwara State, Nigeria, and conveyed in plastic aquaria containing water from the hatchery to the Fisheries and Hydrobiology Laboratory, Department of Zoology, University of Ilorin, Nigeria. To reduce stress-induced mortality to the barest minimum, the fish were starved of food before transportation commenced and upon arrival at the laboratory until the next day. The fish were acclimatised to laboratory conditions in a 150-L capacity holding tank containing aerated borehole water (temperature: $23.25 \pm 1.68{ }^{\circ} \mathrm{C}, \mathrm{pH}: 7.31 \pm 0.83$, dissolved oxygen: $7.46 \pm 0.98 \mathrm{mg} / \mathrm{l})$ for 14 days before the experiment, and were fed with conventional feed pellet at $3 \%$ body weight twice daily. Water renewal was done on daily basis to prevent fish mortality which may arise due to pollution caused by unconsumed feed pellets, and a 12-h diurnal and 12-h nocturnal cycle was maintained. After a 2-week acclimation, the concentration of POME for the experiment was chosen following an earlier study conducted. A preliminary acute toxicity test was carried out following the OECD (OECD 1992) protocols to determine the value of $96-\mathrm{h} \mathrm{LC}_{50}$ after a presumptive or range-finding test had been undertaken. For sub-chronic toxicity assay, concentrations in each test media were modestly maintained below the $96 \mathrm{~h} \mathrm{LC}_{50}$ value obtained as $40.34 \mathrm{mg} / \mathrm{l}$. Based on this value, three different concentrations: 0.00 (control), 4.00, 8.00 and $12.00 \mathrm{mg} / \mathrm{l}$ equivalent to approximately 10,20 and $30 \%$ of the $96 \mathrm{~h} \mathrm{LC}_{50}$ value, respectively, were selected. To each of these concentrations, three replicates of ten acclimated fish of equal weight and size were introduced spanning 28 days. Each of the experimental media was renewed every $24 \mathrm{~h}$ with fresh POME, and fish were fed with conventional pellets twice a day at $3 \%$ body weight. The $\mathrm{pH}$, temperature and dissolved oxygen of the media were checked daily using a digital probe instrument CS-C933T Electrochemistry multimetre (Topac Instrument, Inc., USA), while conductivity was estimated using a conductivity metre (Eutech EC Tester 11 Pocket-tester) and biological oxygen demand (BOD) using a BOD metre (Aqualytic Sensor System, AL606).

\section{Haematological sampling and analysis}

Blood samples from both the control and the treatment groups were collected following the procedure described by Owolabi (2011). Blood was divided into two equal parts: the first part was immediately used in haematological parameters estimation, while the second part was centrifuged at $3000 \mathrm{rpm}$ at $4{ }^{\circ} \mathrm{C}$ for $15 \mathrm{~min}$ after clotting to obtain the serum utilised in the determination of biochemical parameters. RBCs and WBCs were evaluated with the use of Neubauer haemocytometer as described by Dacie and Lewis (2001). Haemoglobin (HB) 
was estimated by cyanmethemoglobin procedure (Blaxhall and Daisley 1973), while packed cell volume (PCV) was evaluated using the microhaematocrit method (Jain 2000). Erythrocyte indices: mean cell volume (MCV), mean cell haemoglobin $(\mathrm{MCH})$ and mean cell haemoglobin concentration $(\mathrm{MCHC})$ were assessed via Dacie and Lewis's (2001) formulae.

\section{Determination of biochemical parameters}

Fish samples from the control and the treatment groups were carefully dissected using dissecting kit, and one gram each of the gill and liver samples was excised, weighed and homogenised with $5 \mathrm{ml} 0.1 \mathrm{M}$ phosphate buffer saline in ice-cold condition using Glass/PTFE potter Elvehjem tissue homogeniser (Omni International, Kennesaw, GA). The homogenates were filtered and centrifuged at $1600 \mathrm{rpm}$ at $4{ }^{\circ} \mathrm{C}$ for $15 \mathrm{~min}$. The supernatants thus obtained were stored at $-20{ }^{\circ} \mathrm{C}$ prior examination. Serum and tissue ALT and AST activities were evaluated according to the procedures of Reitman and Frankel (1957). LDH was estimated following the methods of Vassault and Bergmeyer (1983). The procedure of Aebi (1984) was used for the determination of catalase (CAT), while superoxide dismutase (SOD) was assayed by the methods of Misra and Fridovish (1972). Glutathione peroxidase (GPx) activity was measured using the methods described by Paglia and Valentine (1967). Thiobarbituric (MDA) levels were estimated following the method of Mihara and Uchiyama (1978). For the determination of the electrolytes $\left(\mathrm{Ca}^{+}, \mathrm{K}^{+}, \mathrm{Mg}^{2+}\right.$ and $\left.\mathrm{Na}^{+}\right)$in the tissue samples, approximately $0.5 \mathrm{~g}$ each of the gill and liver was macerated using pestle and mortar and $5 \mathrm{ml}$ perchloric acid added. Samples were then centrifuged at $3000 \mathrm{rpm}$ for $15 \mathrm{~min}$, and the supernatant for each sample was transferred into separate EDTA-containing bottles prior analysis. All the electrolytes were determined using Logaswamy et al. (2007) procedures.

\section{Statistical analysis}

Data were presented as mean \pm standard error. One-way analysis of variance (ANOVA) on SPSS (Version 20.0) software (IBM SPSS Inc., USA) was used for data analysis. Normality of data distribution was determined using the Shapiro-Wilk test, and this was followed by parametric one-way analysis of variance (ANOVA) with Tukey multiple-range test to detect, if any, any significant differences among the experimental groups at probability levels below 0.05 (i.e. $p<0.05$ ).

\section{Results}

Table 1 shows the physicochemical parameters and heavy metal content of the raw POME sampled from Okeawon River near Ogbomoso, South west, Nigeria.
The $\mathrm{pH}$ of POME sample was acidic $(5.78 \pm 0.32)$ and high TDS (2.036.02 \pm 186.23$), \quad$ BOD $(236.9 \pm 26.50)$, COD (1.992.04 \pm 71.18$)$, total alkalinity $(512.76 \pm 31.44)$, nitrates $(68.23 \pm 7.81)$, sulphates $(169.20 \pm 16.43)$, chloride $(626.09 \pm 23.10)$ levels. All the heavy metals investigated were relatively high. In comparison with the standards of both the local and the international regulatory bodies, these parameters deviated from the allowable benchmarks. Compared to the control, Heteroclarias exposure to varying concentrations of $\mathrm{POME}$ prompted significantly $(p<0.05)$ declined $\mathrm{RBC}, \mathrm{HB}, \mathrm{PCV}, \mathrm{MCV}$, $\mathrm{MCH}$ and $\mathrm{MCHC}$ levels in the serum with an increase in POME concentration. The percentage increase above the control value was also concentration-dependent with the lowest elevation at the highest concentration $(12.00 \mathrm{mg} / \mathrm{l})$. In contrast, WBC exhibited a significant $(p<0.05)$ concentration-dependent increase in the POME-exposed fish compared to the control groups (Fig. 1).

The activities of all the enzymes investigated and the level of lipid peroxidation measured as malondialdehyde (MDA) are as shown in the gill (Fig. 2) and liver (Fig. 3) of Heteroclarias exposed to varying concentrations of POME. In comparison with the control, activities of each of the alanine aminotransferase (ALT), aspartate aminotransferase (AST) and lactate dehydrogenase (LDH) in the gill and liver were found to be significantly $(p<0.05)$ higher in all the concentrations, with the highest activity of each enzyme recorded at the highest $(12.00 \mathrm{mg} / \mathrm{l})$ concentration of toxicant. The amplitude of increase over the control for each of ALT, AST and LDH in the gill (Fig. 2) ranged from 21.64 to $67.21 \%, 10.29$ to $33.67 \%$ and 6.57 to $42.99 \%$, respectively, while in the liver (Fig. 3), the amplitude of increase over the control was 16.05 to $48.90 \%, 4.91$ to $19.82 \%$ and 6.42 to $20.60 \%$ for ALT, AST and LDH, respectively. The highest amplitude of increase was observed at the highest exposure concentration. A similar significant ascending trend in the activities of the antioxidants [glutathione peroxidase (GPx), superoxide dismutase (SOD) and catalase (CAT)] in the gill and liver with an increase in toxicant concentration was also observed (Figs. 2, 3). The amplitude of increase over the control in the activity of each of the antioxidant and MDA was also found to be at peak at the highest POME treatment (Figs. 2, 3). Exposure to varying concentrations of POME provoked a significant $(p<0.05)$ upsurge in MDA level in the gill relative to the control, but in the liver MDA level was insignificantly $(p>0.05)$ different compared to the control in all the treatments (Figs. 2, 3).

Exposure of Heteroclarias to sublethal concentrations of POME for 28 days slightly altered the levels of all the electrolytes examined in both the gill and liver compared to the control (Table 2). Generally, the concentration of 
Table 1 Physico-chemical characteristics of palm oil effluents to which Heteroclarias were exposed for 28 days

\begin{tabular}{|c|c|c|c|c|c|c|c|}
\hline & \multirow[t]{2}{*}{ Value } & \multicolumn{3}{|c|}{ Local regulatory limit } & \multicolumn{3}{|c|}{ International regulatory limit } \\
\hline & & NSDWQ (2005) & NIS (2007) & NESREA (2011) & TDIW (1997) & USEPA (2011) & WHO (2011) \\
\hline \multicolumn{8}{|c|}{ Physico-chemical parameter } \\
\hline Temperature $\left({ }^{\circ} \mathrm{C}\right)$ & $36.58 \pm 7.90$ & $30-32$ & N/A & N/A & N/A & & $30-32$ \\
\hline $\mathrm{pH}$ & $5.78 \pm 0.32$ & $6.50-8.50$ & $6.50-9.50$ & $6.00-9.00$ & $5.00-9.00$ & $6.50-8.50$ & $6.50-8.50$ \\
\hline $\mathrm{EC}(\mu \mathrm{S} / \mathrm{cm})$ & $823.25 \pm 70.31$ & $\mathrm{~N} / \mathrm{A}$ & 1000 & N/A & N/A & N/A & 1,000 \\
\hline TDS (mg/l) & $2,036.02 \pm 186.23$ & 500 & 500 & 500 & N/A & 500 & $<1000$ \\
\hline $\mathrm{BOD}(\mathrm{mg} / \mathrm{l})$ & $256.90 \pm 26.50$ & N/A & N/A & 50 & $<100$ & 250 & $\mathrm{~N} / \mathrm{A}$ \\
\hline $\mathrm{COD}(\mathrm{mg} / \mathrm{l})$ & $1.992 .04 \pm 71.18$ & N/A & N/A & 90 & $<1000$ & 410 & $\mathrm{~N} / \mathrm{A}$ \\
\hline Total alkalinity (mg/l) & $512.76 \pm 31.44$ & N/A & NA & 150 & N/A & 20 & N/A \\
\hline Nitrates $\left(\mathrm{NO}_{3}^{-} \mathrm{mg} / \mathrm{l}\right)$ & $68.23 \pm 7.81$ & N/A & 50 & 10 & N/A & 10 & 50 \\
\hline Sulphate $\left(\mathrm{SO}_{4}^{2} \mathrm{mg} / \mathrm{l}\right)$ & $169.20 \pm 16.43$ & N/A & 100 & N/A & N/A & N/A & 500 \\
\hline Chloride (mg/l) & $626.09 \pm 23.10$ & $>1.50$ & 250 & N/A & N/A & 250 & $\mathrm{~N} / \mathrm{A}$ \\
\hline \multicolumn{8}{|l|}{ Metal content (mg/l) } \\
\hline Copper (Cu) & $1.42 \pm 0.22$ & N/A & 1000 & 0.5 & N/A & 1.3 & 2000 \\
\hline Cadmium (Cd) & $0.91 \pm 0.03$ & N/A & 0.003 & 0.2 & N/A & 0.01 & 0.003 \\
\hline Chromium (Cr) & $0.68 \pm 0.21$ & $\mathrm{~N} / \mathrm{A}$ & & & $\mathrm{N} / \mathrm{A}$ & & \\
\hline Iron (Fe) & $0.39 \pm 0.01$ & N/A & 0.300 & $\mathrm{~N} / \mathrm{A}$ & N/A & 0.3 & N/A \\
\hline Lead (Pb) & $0.18 \pm 0.02$ & 0.01 & 0.01 & 0.05 & N/A & 0.02 & 0.01 \\
\hline Zinc $(Z n)$ & $4.03 \pm 0.05$ & N/A & 3000 & & $\mathrm{~N} / \mathrm{A}$ & 5 & N/A \\
\hline
\end{tabular}

EC electrical conductivity, TDS total dissolved solids, BOD biological oxygen demand, COD chemical oxygen demand, NSDWQ Nigeria Standard drinking water quality, NIS Nigeria Industrial Standard, NESREA National Environmental Standard Regulation Enforcement Agency, TDIWThai Department of Industrial Works, USEPA United States Environmental Protection Agency, WHO World Health Organization, N/A not available

the electrolytes in the gill and liver appeared to be stable. However, the gill exhibited an increase in $\mathrm{Ca}^{+}, \mathrm{K}^{+}$, $\mathrm{Mg}^{2+}$ and $\mathrm{Na}^{+}$levels at the highest toxicant concentration $(12.00 \mathrm{mg} / \mathrm{l})$ with a rise of $77.93,38.46,109.54$ and $41.99 \%$ recorded for the electrolytes above the control value, respectively. The concentrations of the $\mathrm{Ca}^{+}$ions in the gill at 4.00 and $8.00 \mathrm{mg} / \mathrm{l}$ of the toxicant recorded insignificant $(p>0.05)$ values compared to the control, though higher values above the control were recorded. In the liver, the trend of electrolytes concentrations was somewhat similar, with the highest percentage increase of 79.17, 26.92, 55.48 and $38.78 \%$ above control recorded for each electrolyte at the maximum concentration of POME (Table 2). The concentrations of all the electrolytes except $\mathrm{K}^{+}$were higher in the gill compared to the liver and were in the order: $\mathrm{Na}^{+}>\mathrm{K}^{+}>\mathrm{Mg}^{+}>\mathrm{Ca}^{2+}$ in each tissue.

\section{Discussion}

The characterised water quality parameters were more than the maximum desirable thresholds recommended by both the local (NSDWQ 2005; NIS (Nigerian Industrial Standard) 2007; NESREA 2011) and international (TDIW 1997; USEPA (United States Environmental protection Agency) 2011; WHO (World Health Organisation) 2011) regulatory bodies, thus indicating the extent of POME toxicity. The BOD value is also higher than the
European Union's recommended maximum threshold $(3.0-6.0 \mathrm{mg} / \mathrm{l})$ for good quality water that could support a blooming fisheries; since uncontaminated water typically have a BOD value equal to or less than $2 \mathrm{mg} / \mathrm{l}$, while that of polluted water could be equal to $10 \mathrm{mg} / \mathrm{l}$ or more. Similarly, the COD value in this study surpassed the EU benchmark $(\leq 20 \mathrm{mg} / \mathrm{l})$ for unpolluted water and the $20-200 \mathrm{mg} / \mathrm{l}$ value recommended for contaminated waters by Chapman (1996). The greater concentration of all the metal contents of the POME than the NIS (2007) and (WHO (World Health Organisation) 2011) recommended benchmarks for surface waters is an indication that wastes containing such metals are being deposited around the oil mill area. The deposition of wastes containing such metals in the oil mill area is inimical to the aquatic ecosystems as it could deteriorate the quality of water by depleting the dissolved oxygen and biomagnified in the food chain when released into water bodies. The acidity of the effluents could also negatively affect the fish. The acidic nature of POME could result in the loss of biologically active oxygen in water bodies (Donald 2004), which could in turn lead to oxygen depletion and loss of aquatic lives. Ali et al. (2012) reported that the acidic condition of POME can impinge on the quality of water and the general well-being of resident aquatic organisms. The lack of proper and adequate waste disposal 

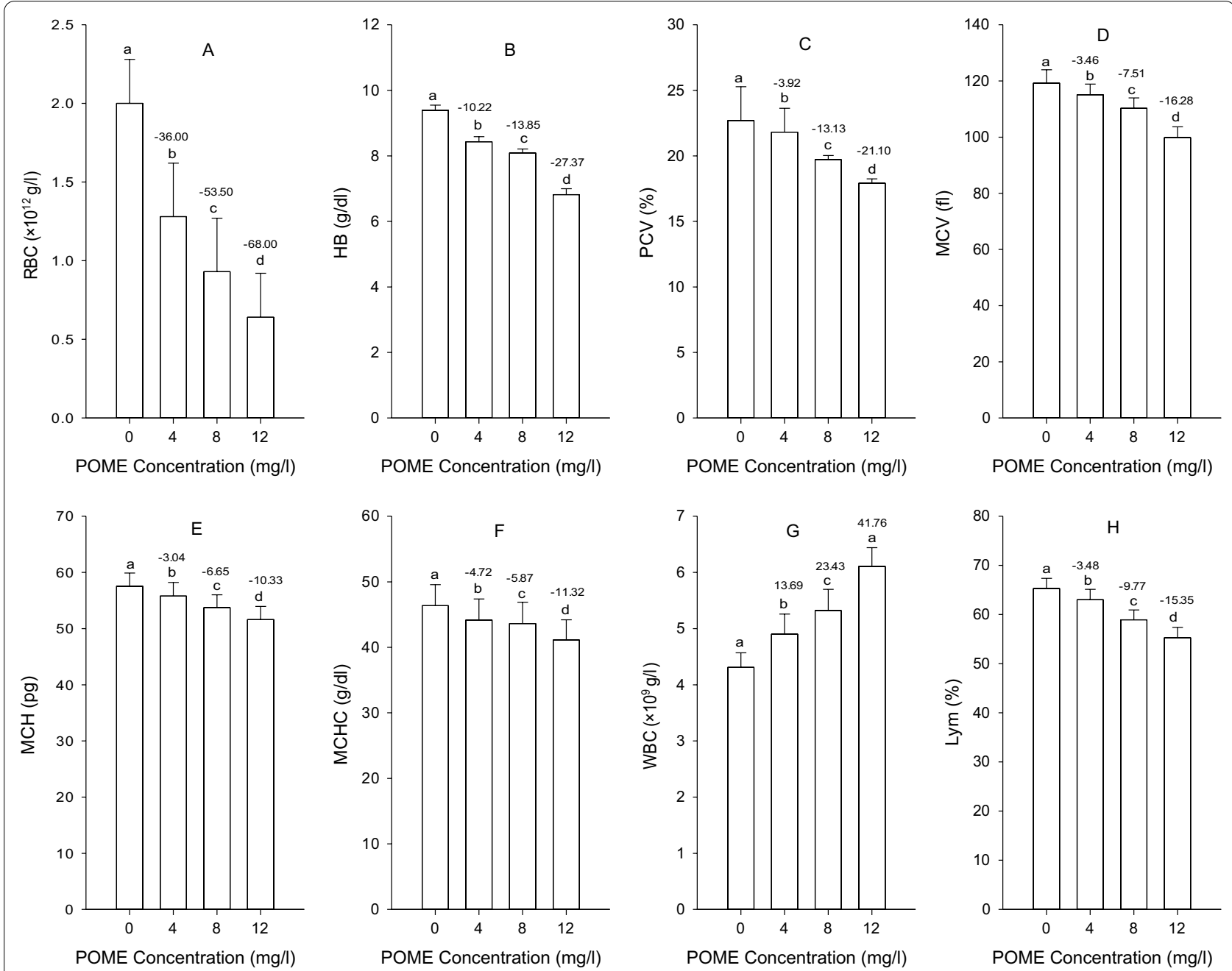

Fig. 1 Changes in haematological parameters of Heteroclarias exposed to different concentrations of POME for 28 days. a RBC (red blood cells), b HB (haemoglobin), c PCV (packed cell volume), d MCV (mean cell volume), e MCH (mean cell haemoglobin), f MCHC (mean cell haemoglobin concentration), $\mathbf{g}$ WBC (white blood cells) and $\mathbf{h}$ Lym (lymphocytes)

system coupled with inadequate treatment facilities may be attributable to the presence of wastes containing metals and other chemicals in the POME, thereby putting aquatic organisms at a serious health risk. Several studies have shown that wastes produced from palm oil industries are rich in high concentrations of organic and inorganic substances and are characterised by high BOD, COD, TDS, alkalinity and $\mathrm{pH}$, and can deleteriously impact aquatic ecosystem and its organisms (Muliari and Zulfahmi 2016; Muliari et al. 2019, 2020; Awotoye et al. 2011). Excessively high dissolved solids can disrupt the osmotic balance of organisms as they are exposed to changes in osmotic pressure which may result in swelling or dehydration.

Physiological evaluation by way of haematological responses in xenobiotic-exposed fish provides an insight into the devastating impacts of xenobiotics (Kavitha et al.
2010) and has been used as sensitive biomarkers in environmental pollution and health assessment of aquatic biotas (Ayandiran and Dahunsi 2016). The significant reduction in the levels of $\mathrm{RBC}, \mathrm{HB}, \mathrm{PCV}$ and erythrocyte indices (MCV, $\mathrm{MCH}$ and $\mathrm{MCHC}$ ) than the control might have been a fall-out from the effluent haemolytic action unleashed on the RBCs membranes, which could have inhibited the pathways of haemoglobin synthesis. The reduction of these parameters is indicative of microcystic hypochromic anaemic condition emanating from the increasing rate of erythrocytes breakdown at the expense of its formation. This trend of haematological alterations corresponds to the findings of Akinrotimi et al. (2013) on Tilapia guineensis exposed to industrial effluents, Dahunsi and Oranusi (2013) and Alimba et al. (2019) on Clarias gariepinus upon exposure to rubber processing and pharmaceutical effluents, respectively 


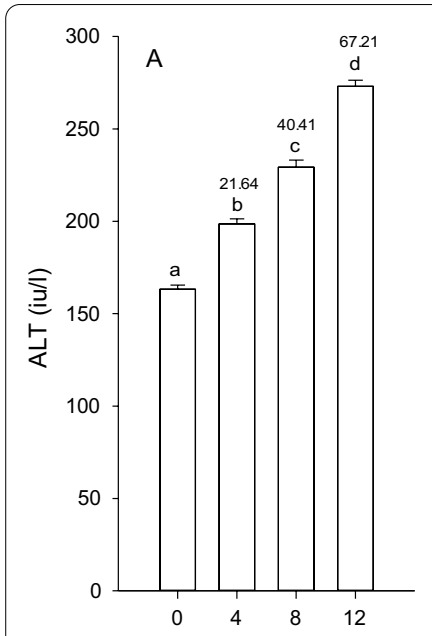

POME Concentration (mg/l)
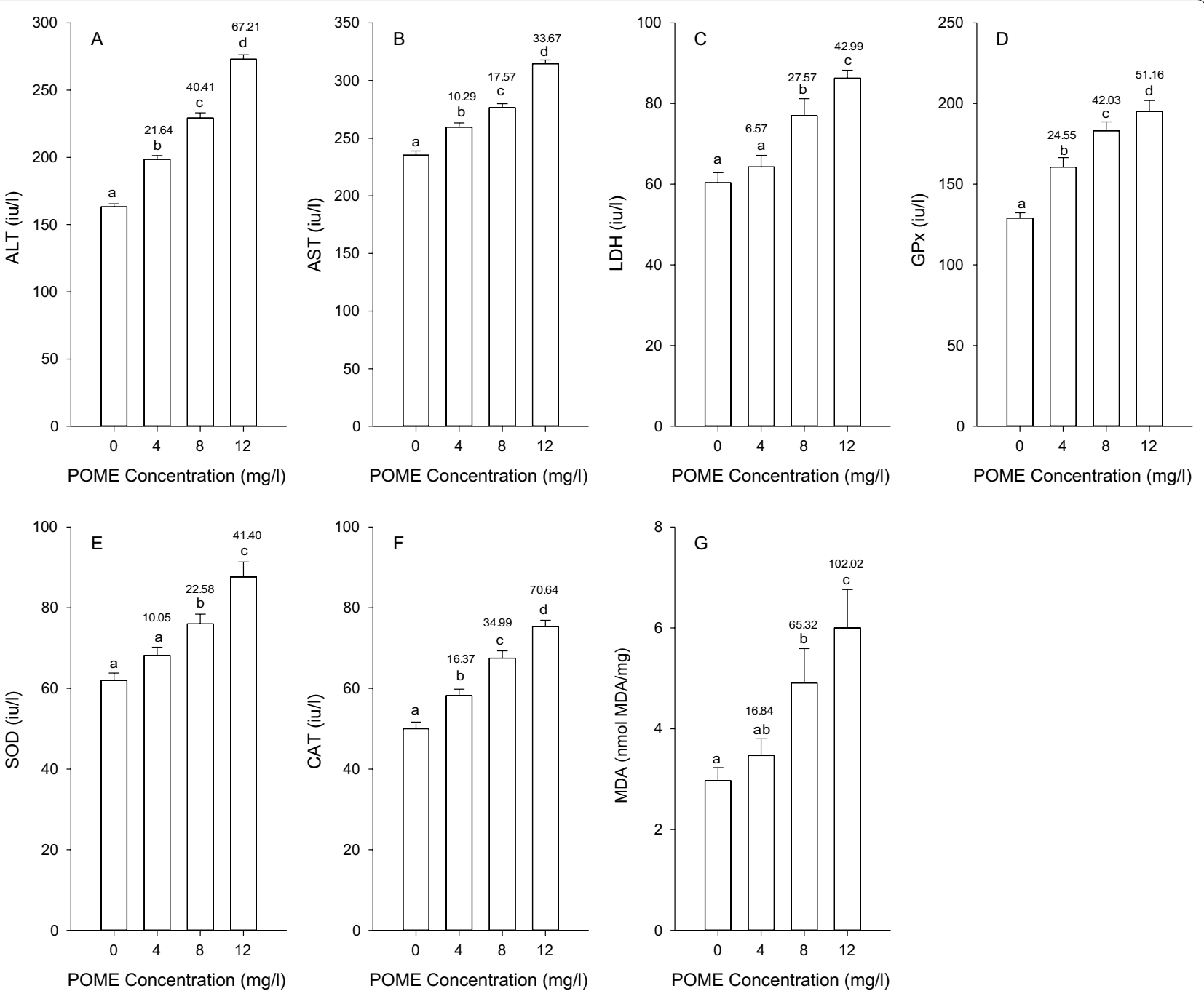

Fig. 2 Biochemical changes in the gill of Heteroclarias exposed to different concentrations of POME for 28 days. a ALT (alanine transaminase), b AST (aspartate transaminase), c LDH (lactate dehydrogenase), $\mathbf{d}$ GPx (glutathione peroxidase), e SOD (superoxide dismutase), f CAT (catalase), g MDA (malondialdehyde)

and that of Juginu et al. (2017) on Labeo rohita exposed to plywood effluent. It has also been reported that there was a progressive decrease in the RBC counts of Labeo rohita in response to an increasing concentration of plywood effluent after 96-h exposure (Juginu et al. 2017). The significant decrease in $\mathrm{MCHC}$ with a rise in toxicant concentration in this study confirms the impairment of haemoglobin synthesis. The decrease in haemoglobin content of the fish blood signifies the constraint in providing enough oxygen to the tissues during hypoxic stress and prolong decrease could lead to weak physical activity such as swimming, thereby making an escape from their predators difficult in the wild. The reduction of these parameters in fish during xenobiotic exposure has been attributed to homeostatic or adaptive responses to structural damage of the blood cells culminating into haemolysis and severe anaemia (Alimba et al. 2019; Ariyomo et al. 2017). The major non-specific immune cells used in evaluating the health status of fish and biomonitoring of aquatic ecosystem are WBC and its differentials (Silva Correa et al. 2017). In this study, the increase in leucocyte numbers (leucocytosis) may be linked to immune-mediated protection from POME toxic effects. Similar observations on leucocytosis have also been made in free-ranging Labeo rohita from Bangalore lake waters contaminated with paint, dye and petroleum effluents (Zutshi et al. 2010), Clarias gariepinus inhabiting industrial, domestic and agricultural waste-polluted El-Rahawy delta, River Nile (Hanan et al. 2013); Channa punctatus from canal receiving effluents from thermal 


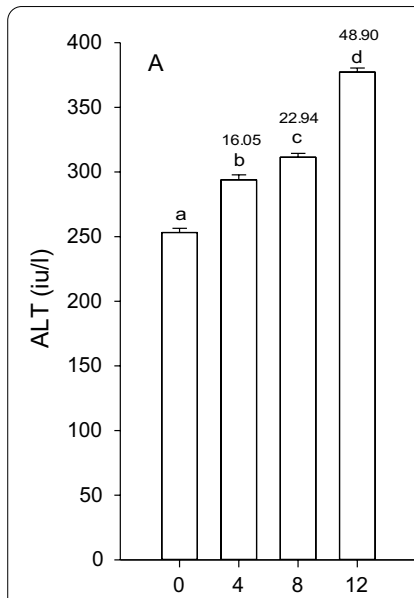

POME Concentration (mg/l)

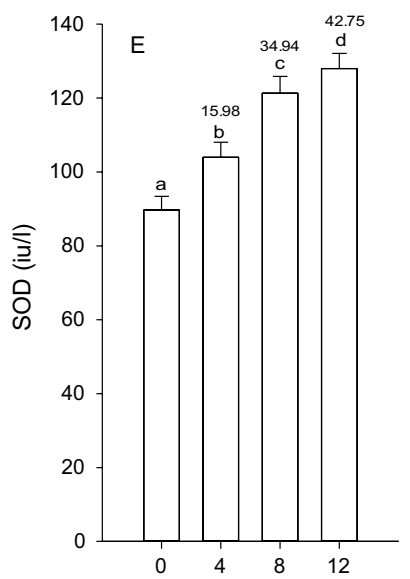

POME Concentration (mg/l)
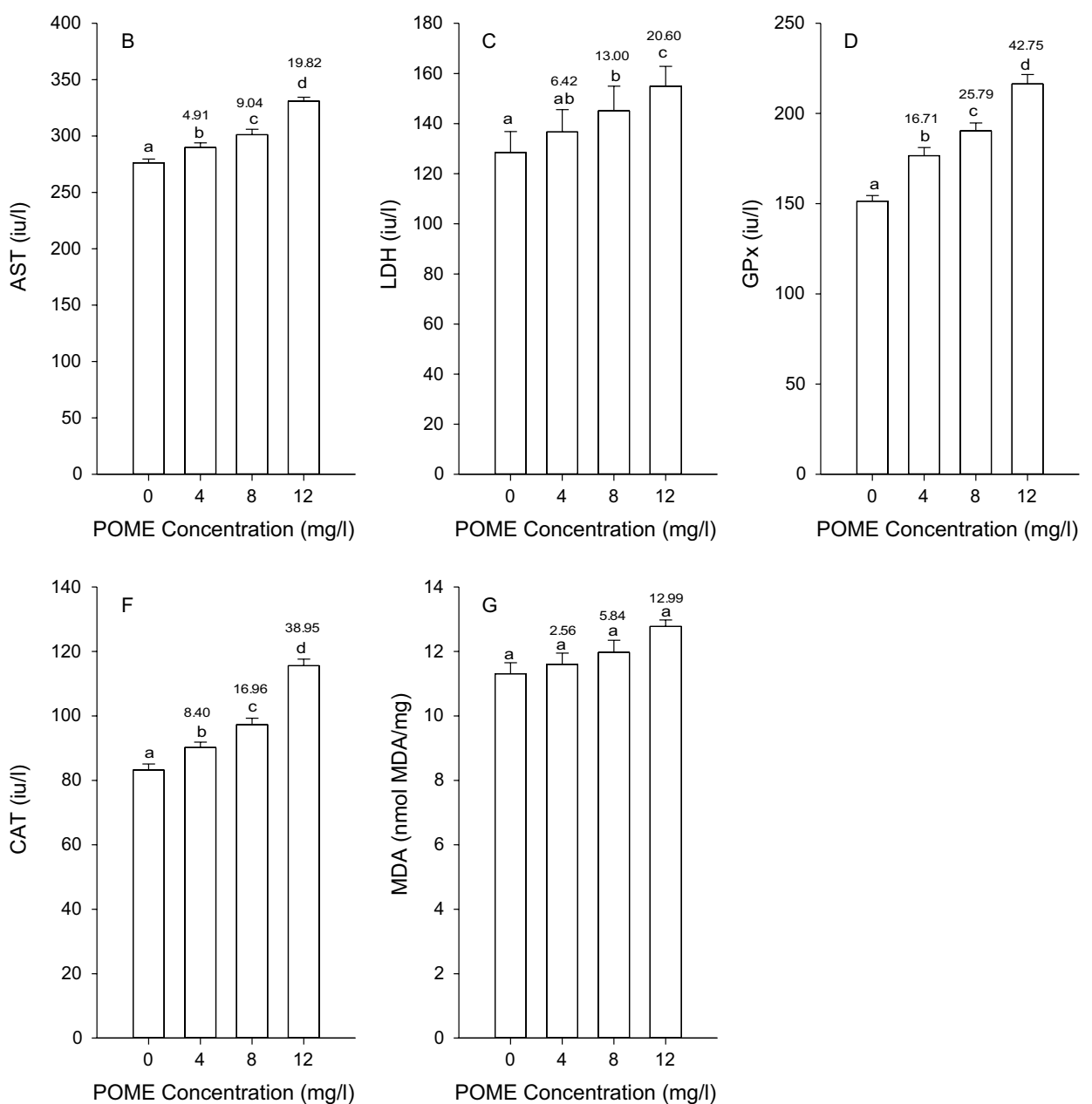

Fig. 3 Biochemical changes in the liver of Heteroclarias exposed to different concentrations of POME for 28 days. a ALT (alanine transaminase), $\mathbf{b}$ AST (aspartate transaminase), c LDH (lactate dehydrogenase), d GPx (glutathione peroxidase), e SOD (superoxide dismutase), f CAT (catalase), g MDA (malondialdehyde)

Table 2 Changes in electrolytes levels in the gill and liver of Heteroclarias exposed to varying concentrations of POME for 28 days

\begin{tabular}{|c|c|c|c|c|c|c|c|c|}
\hline \multirow{4}{*}{$\begin{array}{l}\text { Concentration } \\
(\mathrm{mg} / \mathrm{l}) \text { of POME }\end{array}$} & \multicolumn{8}{|l|}{ Tissue } \\
\hline & \multicolumn{4}{|l|}{ Gill } & \multicolumn{4}{|l|}{ Liver } \\
\hline & \multicolumn{8}{|c|}{ Electrolyte $(\mathrm{mmol} / \mathrm{l})$} \\
\hline & $\overline{\mathrm{Ca}^{2+}}$ & $\mathbf{K}^{+}$ & $\mathrm{Mg}^{2+}$ & $\mathrm{Na}^{+}$ & $\mathrm{Ca}^{2+}$ & $\mathrm{K}^{+}$ & $\mathrm{Mg}^{2+}$ & $\mathrm{Na}^{+}$ \\
\hline 0.00 & $2.22 \pm 0.45^{a}$ & $6.50 \pm 0.19^{a}$ & $3.77 \pm 0.47^{\mathrm{a}}$ & $66.67 \pm 1.01^{\mathrm{a}}$ & $0.48 \pm 0.05^{\mathrm{a}}$ & $10.03 \pm 0.16^{a}$ & $1.37 \pm 0.13^{\mathrm{a}}$ & $55.00 \pm 2.36^{\mathrm{a}}$ \\
\hline 4.00 & $3.34 \pm 0.07^{\mathrm{ab}}$ & $7.00 \pm 0.19^{a b}$ & $5.47 \pm 0.24^{b}$ & $82.33 \pm 0.67^{b}$ & $0.71 \pm 0.02^{b}$ & $10.63 \pm 0.25^{\mathrm{a}}$ & $1.78 \pm 0.15^{\mathrm{ab}}$ & $58.33 \pm 1.79^{\mathrm{a}}$ \\
\hline 8.00 & $3.61 \pm 0.07^{b}$ & $7.37 \pm 0.19^{b}$ & $6.33 \pm 0.45^{b}$ & $85.00 \pm 1.00^{b}$ & $0.80 \pm 0.03^{b}$ & $11.03 \pm 0.26^{\mathrm{a}}$ & $1.93 \pm 0.14^{\mathrm{ab}}$ & $72.00 \pm 6.03^{a b}$ \\
\hline 12.00 & $3.95 \pm 0.05^{b}$ & $9.00 \pm 0.83^{c}$ & $7.90 \pm 0.60^{c}$ & $94.67 \pm 1.00^{c}$ & $0.86 \pm 0.02^{b c}$ & $12.73 \pm 0.63^{\mathrm{ab}}$ & $2.13 \pm 0.14^{b}$ & $76.33 \pm 6.46^{\mathrm{ab}}$ \\
\hline
\end{tabular}

Values are means $\pm S D$ of 3 replicates. Values along the same column with different superscript are significantly $(P<0.05)$ different $\mathrm{Ca}^{2+}$ calcium, $\mathrm{K}^{+}$potassium, $\mathrm{Mg}^{2+}$ magnesium, $\mathrm{Na}^{+}$sodium

power plant (Javed et al. 2016) and several other fish species exposed to different xenobiotics under laboratory conditions (Akinrotimi et al. 2013; Alimba et al. 2019; Juginu et al. 2017). 
The concentration-dependent increase in WBCs shows the increasing attempt by the fish to eliminate the toxicity of the effluent from the body and this validates the earlier observations of Zutshi et al. (2010) and Javed and Usmani (2012) that increase in WBCs during xenobiotic exposure directly correspond to the extent of damage caused by the stressor. Lymphocytes, type of white blood cells which are fundamentally concerned with immune reactions, are necessary for body defence against xenobiotic injury. The dissolved solids and other particulate matter contained in the effluent are capable of clogging the gill apparatus of fish (FAO 1991). The adhesion of POME to the gill surfaces, in this case, might have resulted in severe injuries and oxidative stress, thus stimulating the immune defence system. In this study, the reduction in lymphocyte counts could be consequent of redeployment or redistribution of these cells from blood circulation to other tissues as a result of the stimulation of the immune system. The probable redistribution of these cells towards the gill and other possible sites of injury due to POME toxicity may be a coping strategy to enhance the fish immune system in response to POME-induced stress, and to prevent the fish from the destructive inflammatory action of POME on the tissues; as a result of which the number of lymphocytes in the blood circulation declined. Monocytes, a typical agranulocyte blood cells like the lymphocytes, have been reported to be capable of migration to peripheral tissues for the absorption of foreign materials in response to inflammation (Silva Correa et al. 2017). The decrease in the number of lymphocytes (lymphocytopenia) is consistent with previous observations (Chen et al. 2002) and has been associated with chronic xenobiotic-mediated stress in fish (Akinrotimi et al. 2013).

ALT and AST are the copious transferase enzymes in fish and they play a considerable role in protein and amino-acid metabolism (Singh and Reddy 1990) and are used as biomarkers of environmental contaminants, tissue injuries and the health status of fish. In the present study, the significant ascending trend shown by ALT and AST activities with an increase in POME concentration is indicative of compensatory mechanisms against tissue damage (Ramesh et al. 2014). The gill and liver are rich in ALT and AST. In this study, the probable damage to the branchial and hepatic tissues may be attributable to the significant increases in these enzymes. Following damage to these tissues, they are released into the general blood circulation, hence increase in their activities is suggestive of water contamination (Vaglio and Landriscina 1999). Previous studies have reported similar increases in ALT and AST after fish exposure to acute or chronic concentrations of toxicants (Ogueji et al. 2020). LDH is an enzyme of the anaerobic metabolic pathway that catalyses the reversible conversion of lactate to pyruvate with the reduction of $\mathrm{NAD}^{+}$to $\mathrm{NADH}$ and vice versa. It is usually expressed during tissue damage and so it is a useful diagnostic biomarker of injuries and diseases. An increase in the anaerobic or hypoxic conditions in the fish tissues following POME-induced stress may directly be associated with the significant rise in the activity of LDH. This is because POME exposure might have disrupted energy or ATP production via oxidative phosphorylation, hence the tissues have to produce energy using alternative metabolism, probably through the anaerobic pathway. Another probable reason for the increased LDH activity could be linked to POME inhibitory effects on the mechanisms of oxygen and carbon dioxide exchange in the gills, with resultant use of substitute (anaerobic) pathways in the tissues to survive the POME-imposed stress (Valerio-Garcial et al. 2017; Zeumar et al. 2020). Increased LDH activity has been reported in the gill and liver of fish exposed to various toxicants (Mirghaed et al. 2018).

POME is potentially an inhibitor of aerobic metabolism as it causes oxidative stress and this is reflected in the elevated MDA levels in the gill of Heteroclarias. The breakdown of polyunsaturated fatty acids results into the production of MDA and it is considered an important index of the extent of lipid peroxidation determination (Li et al. 2016). Induction of peroxidation by oxygen radicals has been implicated as the origin of several debilitating disorders and diseases such as haemolysis (Kawatsu 1969), dietary muscular dystrophy (Murai and Andrew 1974) and jaundice (Sakai et al. 1998) in fish. The significant rise in the levels of MDA in the gill of experimental fish is indicative of increased oxidation of molecular oxygen $\left(\mathrm{O}_{2}\right)$ for the production of superoxide radicals. This process might have been responsible for the production of hydrogen peroxide $\left(\mathrm{H}_{2} \mathrm{O}_{2}\right)$, which initiated the peroxidation of unsaturated fatty acids in the membrane leading to the production of MDA (Sreejal and Jaya 2010), causing oxidative damage to the gill. Increased MDA levels have been detected in the tissues of fish inhabiting contaminated waters (Kaptaner et al. 2016).

Environmental contaminants are known to cause disequilibrium between ROS and antioxidant defence system of fish. This defence system, mediated by cascades of antioxidant enzymes, is known to play a key role in ROS sequestration and subsequent conversion to less toxic substances. These enzymes comprise SOD, CAT and GPx, which have been used as biomarkers of oxidative stress in aquatic biotas such as fish (Ogueji et al. 2020; Kaptaner et al. 2016). The SOD-CAT system is regarded as the first line of the defence system against oxidative damage. SOD, a metalloenzyme, offers protection against endogenous superoxide anion by catalysing the reaction 
in which superoxide radicals $\left(\mathrm{O}_{2}{ }^{-}\right)$are transformed into water $\left(\mathrm{H}_{2} \mathrm{O}\right)$, hydrogen peroxide $\left(\mathrm{H}_{2} \mathrm{O}_{2}\right)$ and molecular oxygen $\left(\mathrm{O}_{2}\right)$, while CAT and GPx detoxify the $\mathrm{H}_{2} \mathrm{O}_{2}$ produced during the activity of SOD against superoxide anion radical. The concentration-dependent activation of SOD activity is suggestive of increased deleterious effects of superoxide radicals emanating from a higher concentration of POME. The increased activation of SOD activity is to render less toxic the deleterious effects of radicals and prevents the integrity of cellular membranes from being compromised. Chang et al. (2019) also reported that induction of SOD activity in municipal sewage treatment plant effluent (MSTPE)-exposed crucian carp (Carassius auratus) may be due to the formation of a certain amount of oxygen radicals $\left(\mathrm{O}_{2}^{-}\right)$, and thus enhanced SOD activity became inevitable to catalyse $\mathrm{O}_{2}^{-}$to $\mathrm{H}_{2} \mathrm{O}_{2}$. This result is also comparable to the reports of previous authors (Kaptaner et al. 2016; Ekaete 2014) who reported a significant increase in SOD activity in the gill and liver of fishes inhabiting polluted waters.

CAT is a heme-containing enzyme that facilitates the degradation of $\mathrm{H}_{2} \mathrm{O}_{2}$ to oxygen $\left(\mathrm{O}_{2}\right)$ and water $\left(\mathrm{H}_{2} \mathrm{O}\right)$, thus inhibiting the free radical-imposed stress (Bertrand et al. 2016). The elevated levels of CAT in the gill and liver with increasing concentration of POME may also be attributed to the increased toxic effects of $\mathrm{H}_{2} \mathrm{O}_{2}$ arising from the degradation of superoxide anions via the activity of SOD. The elevation may be an attempt by the tissues to be reprieved from the toxic oxyradicals. Previous scientific observations demonstrating increased activity of CAT in field and laboratory studies on fish exposed to xenobiotics have been made (Kaptaner et al. 2016; Chang et al. 2019; Novoa-Luna et al. 2016). GPx, a selenoenzyme antioxidant, plays an active part in the reduction of $\mathrm{H}_{2} \mathrm{O}_{2}$ to water and lipid hydroperoxides and thus protects cells from oxyradical-induced damage. The present results also show an increasing pattern of GPx as POME concentration increases. Environmental contaminants are widely recognised as inducers of increased activities of GPx in response to oxyradicals (Kaptaner et al. 2016). Increased activities of GPx in fish gill, liver and other tissues were also observed after xenobiotic exposure (Kaptaner et al. 2016). The observations from this study revealed that sublethal concentrations of POME induced the activity of SOD in a pattern parallel with CAT and GPx activities. This may not be strange as they operate in tandem with each other to offset the hazardous effects of free radicals (Chang et al. 2019). Vlahogianni et al. (2007) reported that SOD may act as a signal of oxidative stress, through which the antioxidant enzymes such as CAT or GPx concerned with the elimination of stress can be triggered to action. The participation of lipid peroxidation in the regulation of some antioxidant enzymes (Bagnyukova et al. 2006) and its progressive increase as observed in this study and other previous works (Novoa-Luna et al. 2016) have been used to explain the tripartite increase in SOD, CAT and GPx activities. The increase in SOD activity similarly triggers the increase in $\mathrm{H}_{2} \mathrm{O}_{2}$ formation that was compensated by the induction of CAT and GPx in a bid to obviate the lipid peroxidation and oxidative injury caused by POME. The significant elevation in their activities accentuates their role as key enzymes involved in the protection of biological membranes from hazardous products of free radical reactions and this is a reflection of the normal activity of antioxidant enzymes in response to increased oxidative stress.

In animal tissues, electrolytes are distributed in the body fluids and are involved in buffer systems maintenance to facilitate a proper intra- and extracellular acidobasic equilibrium (Tella 2005). They maintain osmotic pressure of body fluids, regulate the proper functioning of the heart and muscle, act as co-factors for enzymes and also play a key role in redox processes (Mohanty and Mishra 1983). In fish, these highlighted functions may be compromised considering the challenges of maintaining water and electrolyte balance in the face of water-borne contaminants. Hence, one of the mechanisms by which fish and other aquatic biotas could surmount osmotic stress is to maintain electrolyte balance in their tissues. Blood electrolytes are in equilibrium with that of the tissues, so deviation from the equilibrium either below (hypo) or above (hyper) may be due to interference in the blood and tissues ionic equilibrium (Suvetha et al. 2010). Prasad and Reddy (1994) reported that serum electrolytes $\left(\mathrm{K}^{+}, \mathrm{Cl}^{-}\right.$and $\left.\mathrm{Na}^{+}\right)$elevation in atrazine-exposed Tilapia mossambicus may be due to their concomitant reduction in the tissues. Conversely, in the present study, it is not strange to hypothesise that the elevations of $\mathrm{Ca}^{+}, \mathrm{K}^{+}, \mathrm{Mg}^{2+}$ and $\mathrm{Na}^{+}$ions in the POME-exposed fish gill and liver may be consequent to their decrease in the serum/plasma, thus indicating electrolytes disequilibrium and osmoregulatory dysfunction (Prasad and Reddy 1994). Fish gills are known for transportation of respiratory gases and regulation of osmotic and ionic balances. Besides, the gill is the prime organ with which connection is made to the surrounding water and blood for gaseous exchange and osmoregulation. The liver, on the other hand, is responsible for the uptake, biotransformation and elimination of xenobiotics. The individualistic and/or synergistic roles played by these tissues could culminate into a balanced osmoregulatory activity. In fish, damage to the gill and hepatic membranes architecture may result from xenobiotic exposure leading to inhibition of osmoregulatory potential. In this study, exposure to POME demonstrated electrolytes derangement given the significant elevations observed at the highest toxicant 
concentration. This is suggestive of a possible impediment to the structural and functional integrity of the gill and liver membranes as ionic regulatory tissues. Furthermore, the oxidative stress and increased lipid peroxidation measured as MDA observed in the branchial and hepatic tissues might have interfered with the tissue's epithelial membranes and blood membrane homeostasis leading to tissue impairment and electrolytes imbalance. Lipid peroxidation, according to Zaidi et al. (2009), alters tissue membrane organisation and functionality in fish and could result in osmoregulatory dysfunction and/or alterations in electrolytes levels (Lavanya et al. 2011). This condition was earlier validated by Ksheerasagar et al. (2011) who stated that lipid peroxidative injury disrupted the structural and functional integrity of the membrane. Ita and Edagha (2016) also attributed serum potassium and calcium elevations to lipid peroxidation. The marked increase of $\mathrm{Ca}^{+}, \mathrm{K}^{+}, \mathrm{Mg}^{2+}$ and $\mathrm{Na}^{+}$ions in the tissues at the highest toxicant concentration might have also resulted from dehydration due to osmotic efflux of water from the tissues with the retention of the ions therein, thereby contributing to the high rise of tissue electrolytes in POME-exposed fish.

The heavy metal constituents $(\mathrm{Cd}, \mathrm{Cu}, \mathrm{Fe}, \mathrm{Pb}$ and $\mathrm{Zn})$ of POME as revealed in this study have been reported to significantly induced electrolytes levels $\left(\mathrm{Ca}^{+}, \mathrm{K}^{+}, \mathrm{Mg}^{2+}\right.$ and $\mathrm{Na}^{+}$) in the plasma of mice at sublethal exposure (Osuala et al. 2013). Sodium $\left(\mathrm{Na}^{+}\right)$is one of the chief cations of the extracellular fluid, while potassium $\left(\mathrm{K}^{+}\right)$ is an important cation of both the intra-and extracellular fluids. Increased $\mathrm{Na}^{+}$(hypernatremia) as shown in this study have been reported to be dangerous to animals (Gabriel et al. 2009) and this could be due to fish failure to actively eliminate any excess $\mathrm{Na}^{+}$through the gill, liver or kidney. The established induction of a significant increase of $\mathrm{K}^{+}$ions (hyperkalemia) in the tissues of exposed fish might have occurred due to the haemolytic action unleashed by POME on the erythrocytes, which probably resulted from the formation of ROS and partly accounted for the release of $\mathrm{K}^{+}$ions to the tissues. Hyperkalemia has been known to have arisen from the destruction of cells with the consequent redistribution of $\mathrm{K}^{+}$from the intracellular to extracellular compartment (Guyton and Hall 2000) or vice-versa. For comparison purposes, only a few reports exist on the electrolyte levels in fish tissues following toxicants exposure. Elevated $\mathrm{Ca}^{2+}, \mathrm{Mg}^{2+}$ and $\mathrm{K}^{+}$levels have been recorded in the liver, muscle and kidney of textile effluents-exposed Mastacembelus armatus (Karthikeyan et al. 2006). Increased $\mathrm{Na}^{+}$and $\mathrm{K}^{+}$levels were observed in the liver of Clarias gariepinus exposed to fluazifop-p-butyl (Inyang et al. 2016) and linear alkylbenzene sulfonate, a detergent (George and UedemeNaa 2020). These observations agree with the present findings. The hydrogen ion concentration $(\mathrm{pH})$ of the body is strictly under the control of the gill and the kidney. According to Gabriel et al. (2012), a reduction in $\mathrm{pH}$ could result in acidosis, an anomaly of the body. Acidosis, an increase in $\mathrm{H}^{+}$concentration, causes the influx of $\mathrm{H}^{+}$ and efflux of $\mathrm{K}^{+}$across the cells (Ultsch et al. 1981). Such abnormality might have occurred in the gill and liver tissues of fish exposed to POME leading to the exchange of $\mathrm{H}^{+}$and $\mathrm{K}^{+}$cations, thereby inducing the excitability of the skeletal muscles, causing cell lysis and resultant hyperkalemia. Hyperkalemia in fish has also been attributed to a reduction of extracellular spaces (Mathan et al. 2010).

The increase in the concentration of $\mathrm{Ca}^{+}$and $\mathrm{Mg}^{2+}$ in the branchial and hepatic tissues of the POME-exposed fish as observed in this study might be an indication that POME promotes the influx of $\mathrm{Ca}^{+}$and $\mathrm{Mg}^{2+}$ in the gills and liver of fish, respectively. Another reason may also be due to the interference of the toxicant with the activity of the enzyme responsible for the elimination of excess $\mathrm{K}^{+}$.

\section{Conclusions}

The present study showed that the varying chemical constituents of POME (metals, nitrates, chlorides, etc.) were of different concentrations above the allowable limits. Thus, exposure to sub-lethal concentrations of POME potentiated various adverse effects on the antioxidant activities, haemato-biochemical and ionic regulation in the hybrid catfish, Heteroclarias. There is, therefore, the need to prevent the entry of such hazardous effluent into any aquatic medium. The results of this study may be used as a valuable tool in the evaluation of POMEinduced stress in fish and in the formulation of policies and strategies that could be deployed towards preventing the discharge of POME in water bodies in particular and the mitigation of pollution in tropical aquatic ecosystems in general.

\section{Abbreviations}

RBC: Red blood cells; HB: Haemoglobin; PCV: Packed cell volume; MCV: Mean cell volume; MCH: Mean cell haemoglobin; MCHC: Mean cell haemoglobin concentration; WBC: White blood cells; Lym: Lymphocytes; ALT: Alanine transaminase; AST: Aspartate transaminase; LDH: Lactate dehydrogenase; GPx: Glutathione peroxidase; SOD: Superoxide dismutase; CAT: Catalase; MDA: Malondialdehyde; NSDWQ: Nigeria Standard drinking water quality; NIS: Nigeria Industrial Standard; NESREA: National Environmental Standard Regulation Enforcement Agency; TDIW: Thai Department of Industrial Works; USEPA: United States Environmental Protection Agency; WHO: World Health Organization; NA: Not available.

\section{Acknowledgements}

The painstaking efforts of our undergraduate students who did some pilot studies on some aspects of the work are gratefully acknowledged.

\section{Authors' contributions}

ODO conceptualised, designed and participated in supervising the work. He read and corrected the first draft. SIA assisted in the design and supervision 
of the work. She also read and corrected the first draft. AOA is involved in the analysis of data and wrote the first draft. ODO, SIA and AOA read, corrected and approved the final draft of the manuscript. All authors have read and approved the manuscript.

\section{Funding}

Not applicable.

\section{Availability of data and materials Not applicable.}

\section{Declarations}

\section{Ethics approval and consent to participate}

All experiments were carried out following the principles guiding the use and handling of experimental animals as approved by the University of Ilorin Ethical Review Committee (UERC), reference number not applicable, and were in accordance with both the national and international safety regulations and ethical principles for animal welfare.

\section{Consent for publication}

Not applicable.

\section{Competing interests}

The authors declare that they have no competing interests.

\section{Author details}

${ }^{1}$ Fisheries and Hydrobiology Laboratory, Department of Zoology, University of Ilorin, P.M.B. 1515, Ilorin 240003, Nigeria. ${ }^{2}$ Department of Fisheries and Aquculture Technology, Olusegun Agagu University of Science and Technology, Okitipupa, Nigeria.

Received: 25 October 2021 Accepted: 2 December 2021 Published online: 14 December 2021

\section{References}

Aebi H (1984) Catalase in vitro. Methods Enzymol 105:121-126

Akinrotimi OA, Orlu EE, Gabriel UU (2013) Haematological responses of Tilapia guineensis treated with industrial effluents. Appl Ecol Environ Sci 1(1):10-13

Ali HI, Irvan D, Mohammed NA, Arezoo FD (2012) Comparative study on characterisation of Malaysian palm oil mill effluent. Res J Chem Sci 2(12): $1-5$

Alimba CG, Saliu JK, Ubani-Rex OA (2013) Cytogenotoxicity and histopathological assessment of Lekki Lagoon and Ogun River in Synodontis clarias (Linnaeus, 1758). Toxicol Environ Chem 97:221-234

Alimba CG, Adekoya KO, Soyinka OO (2019) Exposure to effluent from pharmaceutical industry induced cytogenotoxicity, haematological and histopathological alterations in Clarias gariepinus (Burchell, 1822). EXCLI J 18:63-78

APHA (American Public Health Association) (2005) Standard methods for the examination of water and wastewater, $21 \mathrm{st}$ edn. American Public Health Association, Washington

Ariyomo TO, Jegede T, Adeniran AF, Omobepade BP (2017) Toxicity of cassava effluents to catfish, Clarias gariepinus and the effect on some target organs. Ann Aquacult Res 4(2):1034

Awotoye OO, Dada AC, Arawomo GAO (2011) Impact of palm oil processing effluent discharge on the quality of receiving soil and river in southwestern Nigeria. J Appl Sci Res 7(2):111-118

Ayandiran TA, Dahunsi SO (2016) Toxicological assessment of fish (Clarias gariepinus) from bitumen-polluted River. Environ Monit Assess 188(71):118. https://doi.org/10.1007/s10661-015-5003-7

Bagnyukova TV, Chahrak OI, Lushchak VI (2006) Coordinated response of goldfish antioxidant defenses to environmental stress. Aquat Toxicol 78(4):325-331

Bertrand L, Asis R, Monferran MV, Ame MV (2016) Bioaccumulation and biochemical response in South American native species exposed to zinc: boosted regression trees as novel tool for biomarkers selection. Ecol Indic 67:769-778

Blaxhall P, Daisley KW (1973) Routine haematological methods for use with fish blood. J Fish Biol 5:771-781

Chan KS, Chooi CF (1984) Ponding system for palm oil mill effluent treatment. In: Proceedings of the regional workshop on palm oil mill effluent technology and effluent treatment PORIM, Malaysia, pp 185-192

Chang T, Wei B, Wang Q, He Y, Wang C (2019) Toxicity assessment of municipal sewage treatment plant effluent by an integrated biomarker response in the liver of crucian carp (Carassius auratus). Environ Sci Pollut Res. https:// doi.org/10.1007/s11356-019-07463-2

Chapman D (1996) Water quality assessment: a guide to the use of biota, sediments and water in environmental monitoring (2nd ed.). Chapman and Hall, London, UK. https://doi.org/10.4324/NOE0419216001

Chen WH, Sun LT, Tsai CL, Song YL, Chang CF (2002) Cold-stress induced the modulation of of catecholamines, cortisol, immunoglobin $\mathrm{M}$ and leucocyte phagocytosis in Tilapia. Gen Comp Endocrinol 126:90-100

da Silva Correa SA, de Souza Abessa DM, dos Santos LG, da Silva EB, Seriani R (2017) Differential blood counting in fish as a non-destructive biomarker of water contamination exposure. Toxicol Environ Chem 99(3):482-491

Dacie JV, Lewis SM (2001) Practical haematology, 9th edn. Churchil Livingstone, London

Dahunsi SO, Oranusi US (2013) Haematological response of Clarias gariepinus to rubber processing effluent. Ann Rev Res 3(4):624-635

Diyaware MY, Haruna AB, Abubakar KA (2013) Some haematological parameters of intergeneric hybrid of African catfish (Clarias anguillaris $x$ Heterobranchus bidorsalis) juveniles and their pure lines in North Eastern Nigeria. J Fish Aquat Sci 8(1):33-42

Donald PF (2004) Biodiversity impacts of some agricultural commodity production systems. Cons Biol. https://doi.org/10.1111/j.1523-1739.2004. 01803.x

Ekaete AG (2014) Oxidative stress in fish living in coastal water polluted with sawdust and wood waste along Lagos lagoon, Nigeria. Researcher 6:1-5

Ezemonye LIN, Ogbeleka DF, Okieimen FE (2007) Acute toxicity of detergent (neatex) and corrosion inhibitor (Norust CR 486) to early stage of Cichlids, Tilapia Guineensis. Chem Ecol 23(2):1-8

FAO (1991) Food and agricultural organisation. African fisheries and the environment. FAO Regional Office, Accra, Ghana

Gabriel UU, Jack IR, Edori OS, Egobueze E (2009) Electrolytes in selected tissues of Heterobranchus bidorsalis treated with sublethal levels of cypermethrin. EJESM 2(3):83-87

Gabriel UU, Akinrotimi OA, Ariweriokuma SV (2012) Alterations of selected electrolytes in organs of African catfish Clarias gariepinus treated with cypermethrin. Adv Stud Res 2(1):53-60

George A, Uedeme-Naa B (2020) Muscle, blood plasma and liver electrolytes of juvenile and adult freshwater catfish, Clarias gariepinus in response to treatment with detergent (Linear alkylbenzene sulfonate). Int J Fish Aquat Stud 8(2):285-292

Guyton AC, Hall JE (2000) Textbook of medical physiology, 10th edn. WB Saunders, Philadephia

Hanan SG, El-kasheif MA, Ibrahim SA, Mohammed MNA (2013) Effect of water pollution in El-Rahawy drainage canal on haematology and organs of freshwater fish Clarias gariepinus. World Appl Sci J 21(3):329-341

Inyang IR, Thomas S, Izah SC (2016) Activities of electrolytes in kidney and liver of Clarias gariepinus exposed to fluazifop-p-butyl. J Biotech Res 2(9):68-72

Ita SO, Edagha IA (2016) Renal protective effect of antioxidant vitamins C and E against crude oil-induced nephrotoxicity. Merit Res J Med Sci 4(9):425-431

Jain NC (2000) Schalm's veterinary haematology (Lea and Fabiger eds). Philadelphia, pp 1120-1125

Javed M, Usmani N (2012) Toxic effects of heavy metals (Cu, Ni, Fe Co, Mn, Cr, $\mathrm{Zn}$ ) to the haematology of Mastacembellus armatus thriving in Harduaganj Reservoir, Aligarh, India. Glob J Med Res 12:59-64

Javed M, Ahmad I, Ahmad A, Usmani N, Ahmad M (2016) Studies on the alterations in haematological indices, micronuclei induction and pathological marker enzyme activities in Channna punctatus (spotted snakehead) Perciformes, Channidae exposed to thermal power plant effluent. Springerplus 5(1):761

Juginu MS, BinuKumari S, Kumar MM (2017) Impact of plywood on the haematological parameters of freshwater fish, Labeo rohita. Int J Fish Aquat Stud 5(1):112-115 
Kaptaner B, Kankaya E, Dogan A, Durmus A (2016) Alterations in histology and antioxidant defense system in the testes of the lake Van fish (Alburnus tarishi Guldenstadt, 1814). Environ Monit Assess 188:474. https://doi.org/ 10.1007/s10661-016-5476-z

Karthikeyan S, Jambulingam M, Sivakumar P (2006) Impact of textile effluents on freshwater fish Mastacembelus armatus (Cuv. \& Val). E-J Chem 3(4):303-306

Kavitha C, Malarvizhi A, Kumaran SS, Ramesh M (2010) Toxicological effects of arsenate exposure on haematological, biochemical and liver transaminases activity in an Indian major carp, Catla Catla. Food Chem Toxicol 48(10):2848-2854

Kawatsu H (1969) Studies on the anaemia of fish-III. An example of macrocytic anaemia found in brook trout, Salvelinus fontinalis. Bull Freshw Res Lab 19:161-167

Ksheerasagar RL, Hiremath MB, Kaliwal DD (2011) Impairment of hepatic biochemical contents and enzymes activities during carbosulfan intoxication in albino mice. Int Multidiscip Res J 1(3):6-15

Lavanya S, Ramesh M, Kavitha C, Malarvzhi A (2011) Haematological, biochemical and ionoregulatory response in Indian major carp Catla catla during chronic sublethal exposure to inorganic arsenic. Chemosphere 82:977-985

Li J, Zheng X, Liu K, Sun S, Li X (2016) Effect of tetracycline on the growth and nutrient removal capacity of Chlamydomonas reinhardtii in simulated effluent from wastewater treatment plants. Bioresour Technol 218:1163-1169

Logaswamy S, Radha G, Ss S (2007) Alterations in the levels of ions in blood and liver of freshwater fish, Cyprinus carpio var. communis exposed to dimethoate. Environ Monit Assess 131:439-444

Mathan R, Kurunthachalam SK, Priya M (2010) Alterations in plasma electrolyte levels of a freshwater fish Cyprinus carpio exposed to acidic pH. Toxicol Environ Chem 92(1):149-157

Mihara M, Uchiyama M (1978) Determination of malonaldehyde precursor in tissues by thiobarbituric acid test. Anal Biochem 86:271-278

Mirghaed AT, Yarahmadi P, Harehdasht MS, Craig PM, Farsani HG, Ghysvandi N, Eagderi S (2018) Hemato-immunological, serum metabolite and enzymatic stress response alterations in exposed rainbow trout (Oncorhynchus mykiss) to nanosilver. Int J Aquat Biol 6(4):221-234

Misra HP, Fridovish I (1972) The role of superoxide anion in the autoxidation of epinephrine and a simple assay for superoxide dismutase. J Biol Chem 247:3170-3175

Mohanty BK, Mishra BN (1983) Effect of mercurial drug (kalyoli) on albino rat blood. J Environ Biol 4:2001-2006

Muliari M, Zulfahmi I (2016) Impact of palm oil mill effluent towards phytoplankton community in Krueng Mane River, North Aceh. J Perikanan Dan Kelautan 6:137-146

Muliari M, Zulfahmi I, Akmal Y, Karja NWK, Nisa C, Sumon KA (2019) Effects of palm oil mill effluenton reproductive hormone of female Nile tilapia, Oreochromis niloticus (Linnaeus 1758). Adv Anim Vet Sci 216:1-5

Muliari M, Zulfahmi I, Akmal Y, Karja NWK, Nisa C, Sumon KA et al (2020) Toxicity of palm oil mill effluent on the early life stages of Nile tilapia (Oreochromis niloticus, Linnaeus 1758). Environ Sci Pollut Res. https://doi. org/10.1007/s11356-020-09410-y

Murai T, Andrew JW (1974) Interaction of dietary a-tocopherol, oxidized menhaden oil and ethoxyquin on channel catfish /ctalurus punctatus. J Nutr 104:1416-1431

NESREA (2011) National Environmental Standards and Regulations Enforcement Agency. National environmental (surface and groundwater quality) regulations. Abuja, Nigeria: NESREA, 2011

NIS (Nigerian Industrial Standard) (2007) Nigerian standards for drinking water quality. (NIS 554: 2007, ICS 13.060.20). Standard Organisation of Nigeria (SON) Governing Council

Novoa-Luna KA, Romero-Romero R, Natividad-Rangel R, Galar-Martinez M, SanJuan-Reyes N, Garcia-Medina S, Martinez-Vieyra C, Neri-Cruz N, Gomez-Olivan LM (2016) Oxidative stress induced in Hyalella azteca by an effluent from a NSAID-manufacturing plant in Mexico. Ecotoxicology 25(7):1288-1304. https://doi.org/10.1007/s10646-016-1682-2

NSDWQ (Nigeria Standard for drinking water quality) (2005) National environmental regulations. Nigeria Standard for for drinking water quality, $30 \mathrm{p}$

OECD (1992) Organisation for economic cooperation and development for testing of chemicals. Guideline no. 203: Fish, acute toxicity test. Paris
Ogueji E, Nwani C, Mbah C, Ihenacho S, Nweke F (2020) Oxidative stress, biochemical, lipid peroxidation, and antioxidant responses in Clarias gariepinus exposed to acute concentrations of ivermectin. Environ Sci Pollut Res. https://doi.org/10.1007/s11356-019-07035-4

Okwute OL, Isu NR (2007) Impact analysis of palm oil mill effluent on the aerobic bacterial density and ammonium oxidizers in a dump site in Anyigba, Kogi State. Afr J Biotechnol 6(2):116-119

Osuala FI, Otitoloju AA, Igwo-Ezikpe MN (2013) Sublethal effects of cadmium, manganese, lead, zinc and iron on the plasma electrolytes regulation in mice, Mus musculus. Afr J Environ Sci Technol 7(9):925-931

Owolabi OD (2011) Haematological and serum biochemical profile of the upside-down catfish Synodontis membranacea Geoffroy Saint Hilaire from Jebba Lake, Nigeria. Comp Clin Pathol 20:163-172. https://doi.org/10. 1007/s00580-10-0973-x

Paglia DE, Valentine WN (1967) Studies on the quantitative and qualitative characterisation of erythrocyte glutathione peroxidase. J Lab Clin Med 70:158-169

Prasad TAV, Reddy DC (1994) Atrazine toxicity on hydromineral balance of fish Tilapia mossambicus. Ecotoxicol Environ Saf 28:313-316

Ramesh M, Sankaran M, Veera-Gowtham V, Poopal RK (2014) Haematological, biochemical and enzymological responses in an Indian major carp Labeo rohita induced by sublethal concentration of waterborne selenite exposure. Chem Biol Interact 207:67-73

Reitman S, Frankel S (1957) Colometric method for the determination of serum transaminase activity. Am J Clin Pathol 28:56-68. https://doi.org/ 10.1093/ajcp/28.1.56

Sakai T, Murata H, Endo M, Shimomura T, Yamauchi K, Ito T, Yamaguchi T, Nakajima H, Fukudome M (1998) Severe oxidative stress is thought to be a principal cause of jaundice of yellowtail Seriola quinqueradiata. Aquaculture 160:205-214

Singh HS, Reddy TV (1990) Effect of copper sulfate on hematology, blood chemistry and hepatosomatic index of an Indian catfish, Heteropneustes fossilis (Bloch), and its recovery. Ecotoxicol Environ Saf 20:30-35

Sreejal R, Jaya DS (2010) Studies on the changes in lipid peroxidation and antioxidants in fishes exposed to hydrogen sulfide. Toxicol Int 17(2):71-77

Suvetha L, Ramesh M, Saravanan M (2010) Influence of cypermethrin toxicity on ionic regulation and gill $\mathrm{Na}^{+} / \mathrm{K}^{+}$-ATPase activity of a freshwater teleost fish Cyprinus carpio. Environ Toxicol Pharmacol 29:44-49

TDIW (Thailand Department of Industrial Work) (1997) Environmental management guidelines for the palm oil industry, Thailand, PN 2000.2265.5$001,00,75 \mathrm{pp}$

Tella MA (2005) Serum electrolyte changes in West African dwarf (WAD) sheep with single concurrent (Babesia avis and Trypanosoma congolense) infections. Afr J Biol Res 8:63-65

Tsarpali V, Dailianis S (2012) Investigation on landfill leachate toxic potency: an integrated approach with the use of stress indices in tissues of mussels. Aquat Toxicol 124-125:58-65. https://doi.org/10.1016/j.aquatox.2012.07. 008

Ultsch GR, Ott ME, Heisler N (1981) Acid-base and electrolyte status in Carp (Cyprinus carpio) exposed to low environmental pH. J Exp Biol 93:65-80

USEPA (United States Environmental protection Agency) (2011) Source water assessment USEPA, Office of water. http://water.epa.gov/infrastructure/ drinkingwater/sourcewater/protection/sourcewaterassessments.cfm

Vaglio A, Landriscina C (1999) Changes in liver enzyme activity in the teleost Sparus aurata in response to calcium intoxication. Ecotoxicol Environ Saf 43(1):111-116. https://doi.org/10.1006/eesa.1999.1778

Valerio-Garcial RC, Carbajal-Hernandez AL, Martinez-Ruiz EB, Jarquin-Diaz VH, Haro-Perez C, Martinez-Jeronimo F (2017) Exposure to silver nanoparticles produces oxidative stress and affects macromolecular and metabolic biomarkers in the goodeid fish Chapalichthys pardalis. Sci Total Environ 583:308-318

Vassault A (1983) Lactate dehydrogenase: UV-method with pyruvate and NADH. In: Bergmeyer HU (ed) Methods of enzymatic analysis, 3rd edn. Plenum, New York III, pp 118-125

Vithana CL, Sullivan LA, Shepherd T (2019) Role of temperature on the development of hypoxia in blackwater from grass. Sci Total Environ 667:152159. https://doi.org/10.1016/j.scitotenv.2019.02.386

Vlahogianni T, Dassenakis M, Scoullos M, Valavanidis A (2007) Integrated use of biomarkers (superoxide dismutase, catalase and lipid peroxidase) in mussels Mytilus galloprovincialis for assessing heavy metals pollution 
in coastal areas from the Saronikos Gulf of Greece. Mar Pollut Bull 54(9):1361-1371

WHO (World Health Organisation) (2011) Guidelines on drinking water quality, 4th edn. World Health Organisation, Geneva

World Bank (2018) X-raying the Nigerian palm oil sector. https://www.pwc. com/ng/en/assets/pdf/x-raying-the-nigeria-palm-oil-sector.pdf

Wu TY, Mohammed AW, Jahim J, Anuar N (2009) A holistic approach to managing palm oil mill effluent (POME): biotechnological advances in the sustainable reuse of POME. Biotechnol Adv 27(1):40-52

Zaidi A, Fernandes D, Bean JL, Michelis ML (2009) Effect of paraquat-induced oxidative stress on the neuronal plasma membrane $\mathrm{Ca}^{2+}$-ATPase. Free Radic Biol Med 47(10):1507-1514

Zeumar R, Galhano V, Monteiro MS, Kuehr S, Knopf B, Meisterjahn B, Soares AMVM, Loureiro S, Lopes I, Schlechtriem C (2020) Chronic effects of wastewater-borne silver and titanium dioxide nanoparticles on the rainbow trout (Oncorhynchus mykiss). Sci Total Environ 723:137974

Zulfahmi I, Muliari M, Akmal Y (2017) Hepatosomatic index and liver histopathology of Nile tilapia (Oreochromis niloticus Linnaeus 1758) exposed to palm oil mill effluent. Seminal Nasional Multi Disiplin IImu UNAYA (in Indonesian) 1:301-314

Zulfahmi I, Muliari M, Akmal Y, Batubara AS (2018) Reproductive performance and gonad histopathology of female Nile tilapia (Oreochromis niloticus Linnaeus 1758) exposed to palm oil effluent. Egypt J Aquat Res 44(4):327-332

Zutshi B, Raghu Prasad SG, Nagaraja R (2010) Alteration in haematology of Labeo rohita under stress of pollution from Lakes of Bangalore, Karnataka, India. Environ Monit Assses 168:11-19

\section{Publisher's Note}

Springer Nature remains neutral with regard to jurisdictional claims in published maps and institutional affiliations.

\section{Submit your manuscript to a SpringerOpen ${ }^{\circ}$ journal and benefit from:}

- Convenient online submission

- Rigorous peer review

- Open access: articles freely available online

- High visibility within the field

- Retaining the copyright to your article

Submit your next manuscript at $\boldsymbol{\nabla}$ springeropen.com 